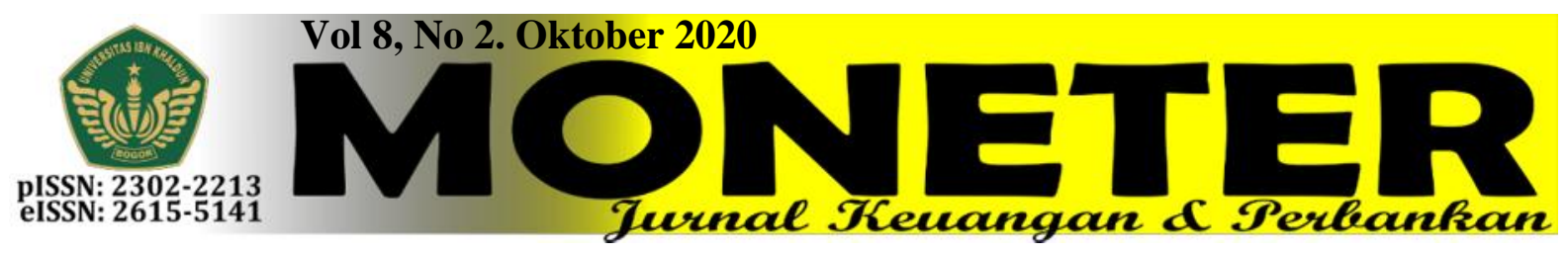

\title{
RETURN SAHAM PERUSAHAAN SUBSEKTOR PROPERTI DAN REAL ESTATE DI INDONESIA: RASIO LIKUIDITAS, RASIO SOLVABILITAS, DEGREE OF LEVERAGE
}

\author{
Oleh: \\ Much. Rizal P. Geno' ${ }^{1)}$, Rizky Windrasta Nuradmanta ${ }^{2)}$, Amrie Firmansyah ${ }^{3)}$ \\ Politeknik Keuangan Negara STAN, Tangerang Selatan ${ }^{1,2,3)}$ \\ Email: \\ much.rizal.pg@gmail.com ${ }^{1)}$,rwindrasta@gmail.com ${ }^{2)}$, \\ amrie.firmansyah@gmail.com ${ }^{3)}$
}

\begin{abstract}
The advantage of investing in the capital market can be reflected in return on the selected shares. Currently, more and more investors are interested in investing in property companies. The property business is up-and-coming due to the high demand from the public and the property's selling price, which tends always to go up. This study examines the effect of liquidity ratios, solvency ratios, and the degree of leverage on stock returns. This study uses a sample of financial data from companies engaged in the property and real estate sub-sector listed on the IDX from 2012 to 2019. This study indicates that solvency positively affects stock returns, while liquidity, operating leverage, and financial leverage do not affect company stock returns.
\end{abstract}

Keywords: Stock Return, Liquidity, Solvency, Financial Leverage, Operating Leverage.

\begin{abstract}
ABSTRAK
Keuntungan dalam berinvestasi di pasar modal dapat dicerminkan melalui perolehan return atas saham yang dipilih. Saat ini, semakin banyak investor yang berminat berinvestasi di perusahaan properti. Bisnis properti sangat menjanjikan dikarenakan tingginya permintaan dari masyarakat dan harga jual properti yang memiliki kecenderungan selalu naik. Penelitian ini bertujuan untuk menguji pengaruh rasio likuiditas, rasio solvabilitas, dan degree of leverage terhadap return saham. Penelitian ini menggunakan sampel data keuangan perusahaan yang bergerak di subsektor properti dan real estate yang terdaftar di BEI pada periode tahun 2012 s.d. tahun 2019. Hasil penelitian ini menunjukkan bahwa solvabilitas berpengaruh positif terhadap return saham sedangkan likuiditas, operating leverage dan financial leverage tidak berpengaruh terhadap return saham perusahaan.
\end{abstract}

Kata Kunci: Return Saham, Likuiditas, Solvabilitas, Financial Leverage, Operating Leverage. 


\section{Pendahuluan}

Perusahaan properti dan real estate adalah perusahaan yang memiliki kepemilikan atas tanah dan bangunan, juga melakukan pemasaran (mencakup menjual ataupun menyewakan) atas kepemilikannya (Kayo, 2020). Perusahaan properti dan real estate menawarkan hunian bagi masyarakat dengan berbagai fasilitas dan kenyamanan. Real estate mencakup usaha pembelian, penjualan, persewaan, dan pengoperasian berbagai macam bangunan tempat tinggal dan bukan tempat tinggal. Saat ini, semakin banyak investor yang berminat untuk berinvestasi di perusahaan properti karena harga tanah yang menjadi kebutuhan utama dalam bisnis ini cenderung naik. Daya tarik investasi saham sektor properti didorong oleh harga properti dan real estate yang cenderung mengalami kenaikan (Jamil dan Utami, 2016). Kenaikan harga ini disebabkan oleh industri properti yang memiliki keterbatasan suplai lahan namun karena tingginya permintaan, harga properti selalu naik. Banyak hal yang harus dipertimbangkan dalam memilih saham yang akan diinvestasikan. Investor memilih saham di bidang properti dengan tujuan untuk memaksimalkan return dengan tidak mengabaikan risiko yang akan dihadapinya.

Keadaan perekonomian yang tidak menentu telah membuat informasi keuangan menjadi sangat penting bagi investor. Penggunaan informasi keuangan oleh pihak luar investor memiliki peran yang besar yaitu sebagai dasar pertimbangan apakah keputusan investasi yang akan diambil, akan mendatangkan keuntungan di masa depan. Kinerja perusahaan merupakan faktor penentu yang digunakan oleh investor dalam membuat keputusan investasi (Astikawati \& Relita, 2017). Investor yang membeli saham perusahaan disebut juga shareholders, yaitu pihak yang memiliki klaim terhadap aliran kas perusahaan. Laporan keuangan yang telah diaudit dapat memberikan gambaran kinerja masa lalu perusahaan dalam mengelola kegiatan operasional, pendanaan, dan investasi. Kinerja saham perusahaan juga dapat dilihat dari pergerakan harga saham perusahaan yang diperdagangkan di pasar modal.

Yuliaratih \& Artini (2018) mengungkapkan bahwa tujuan investor menanamkan modalnya pada sekuritas saham adalah untuk mendapatkan return yang tinggi dengan tingkat risiko tertentu. Oleh karena itu, dalam melakukan investasi sekuritas saham, investor akan lebih menyukai perusahaan yang dapat memberikan return yang lebih tinggi. Untuk bisa mendapatkan return yang diinginkan, investor akan melakukan analisis sendiri pada perilaku perdagangan suatu saham perusahaan, atau dengan menggunakan sarana yang sudah disediakan dari analis di pasar modal, misalnya broker, dealer, dan para manajer investasi. Return saham begitu penting bagi investor, oleh karena itu, dalam penelitian ini return saham dijadikan sebagai variabel dependen. Adapun objek penelitian ini adalah perusahaanperusahaan pada subsektor properti dan real estate yang terdaftar di Bursa Efek Indonesia (BEI) mulai dari tahun 2012 s.d. 2019. Selain itu, kekurangan cash flow dapat membuat suatu perusahaan kesulitan dalam berekspansi atau bahkan mengalami kebangkrutan karena kekurangan uang akibat cash flow yang selalu minus. Maka dari itu, penelitian ini menjadikan likuiditas dan solvabilitas sebagai variabel independen karena likuiditas dan solvabilitas merupakan hal yang penting untuk dipertimbangkan oleh investor. Adapun cara untuk mengukur likuiditas dan solvabilitas yaitu melalui rasio keuangan dan degree of leverage. 
Penelitian terkini sebelumnya terkait return saham dilakukan oleh Sudarsono \& Sudiyatno (2016), tentang pengaruh inflasi, tingkat suku bunga, nilai tukar Rupiah terhadap US Dollar, return on asset (ROA), debt to equity ratio (DER), dan ukuran perusahaan (size) terhadap return saham perusahaan properti dan real estate yang terdaftar di BEI periode tahun 2009 s.d. 2014. Berdasarkan penelitian tersebut dapat disimpulkan bahwa tingkat suku bunga dan nilai tukar Rupiah terhadap US Dollar berpengaruh positif signifikan terhadap return saham, size berpengaruh positif tidak signifikan terhadap return saham, ROA berpengaruh negatif tidak signifikan terhadap return saham, serta inflasi dan DER berpengaruh negatif signifikan terhadap return saham. Penelitian tersebut menyarankan peneliti selanjutnya untuk menambahkan variabel bebas lainnya, seperti quick ratio, current ratio, dan lain lain, serta menambah atau memperpanjang periode penelitian dengan menggunakan data penelitian terbaru untuk mendapatkan hasil penelitian yang lebih bisa mendekati fenomena-fenomena sesungguhnya pada pasar modal Indonesia.

Penelitian lain dilakukan oleh Mende \& Rate (2017) tentang hubungan likuiditas, solvabilitas dan rentabilitas terhadap return saham perusahaan properti dan real estate yang terdaftar di BEI periode tahun 2012 s.d. 2015. Hasil penelitian tersebut memberikan kesimpulan bahwa secara parsial likuiditas (current ratio) tidak berpengaruh signifikan, solvabilitas (DER) tidak berpengaruh signifikan, dan rentabilitas (ROA) tidak berpengaruh signifikan terhadap return saham. Secara bersama-sama, likuiditas, solvabilitas dan rentabilitas juga tidak berpengaruh signifikan terhadap return saham. Penelitian sebelumnya juga pernah dilakukan oleh Sudarman (2017), tentang hubungan likuiditas dan solvabilitas terhadap return saham perusahaan manufaktur yang terdaftar di BEI periode tahun 2013 s.d. 2016. Hasil penelitian tersebut memberikan kesimpulan bahwa profitabilitas mampu menjadi mediasi pengaruh likuiditas (current ratio) dan solvabilitas (DER) terhadap return saham. Hubungan langsung likuiditas dan solvabilitas terhadap return saham tidak signifikan sehingga baik perusahaan maupun investor perlu memperhatikan kinerja keuangannya terutama pada peningkatan profitabilitas. Penelitian lain tentang hubungan operating leverage dan financial leverage terhadap return saham pada perusahan manufaktur industri yang terdaftar di BEI telah dilakukan oleh Syaifullah (2018). Hasil penelitian tersebut memberikan kesimpulan bahwa operating leverage dengan proksi degree of operating leverage (DOL) berpengaruh terhadap return saham sedangkan financial leverage dengan proksi degree of financial leverage (DFL) tidak berpengaruh terhadap return saham.

Penelitian ini menggunakan periode waktu tahun 2012 s.d. tahun 2019 dengan tujuan untuk memberikan hasil penelitian yang lebih terkini dan relevan atas return saham perusahaan di subsektor properti dan real estate. Selain itu, sejak tahun 2012, konvergensi PSAK berbasis International Financial Reporting Standards (IFRS) mulai efektif diberlakukan. Konvergensi PSAK berdampak pada akses perusahaan ke pendanaan internasional yang lebih terbuka karena laporan keuangan akan lebih mudah dikomunikasikan ke investor global (Putra et al., 2019). Selain itu, relevansi laporan keuangan akan meningkat karena lebih banyak menggunakan nilai wajar dan kinerja keuangan (laporan laba rugi) akan lebih fluktuatif apabila harga-harga fluktuatif. Pemilihan perusahaan di sektor properti dan real estate dalam penelitian ini karena perusahaan di sektor ini memiliki prospek yang cerah di masa yang akan datang mengingat potensi jumlah penduduk yang terus bertambah besar, serta semakin banyaknya pembangunan 
di sektor perumahan, apartemen, gedung perkantoran, pusat perbelanjaan, sehingga membuat para investor tertarik untuk menginvestasikan dananya dan perdagangan saham diperkirakan akan terus meningkat.

\section{Tinjauan Pustaka dan Pengembangan Hipotesis}

\subsection{Signalling Theory}

Teori sinyal merupakan konsep dimana pihak pemberi informasi dapat memilih apa dan bagaimana informasi akan ditampilkan dan pihak penerima informasi dapat memilih bagaimana menginter-pretasikan informasi yang diterima (Khairudin \& Wandita, 2017). Sinyal-sinyal informasi yang dibutuhkan oleh investor untuk mempertimbangkan dan menentukan apakah para investor akan menanamkan sahamnya atau tidak pada perusahaan yang bersangkutan dimana informasi mengenai perubahan harga dan volume saham mengandung informasi dalam memberikan bukti yang bermanfaat dan dapat digunakan dalam pengambilan keputusan (Khairudin \& Wandita, 2017).

Menurut Jogiyanto (dalam: 36), informasi yang dipublikasikan sebagai suatu pengumuman akan memberikan sinyal bagi investor dalam pengambilan keputusan investasi (Sudarsono \& Sudiyatno, 2016). Perusahaan baik dapat dibedakan dari perusahaan yang tidak baik dengan mengirimkan sinyal yang dapat dipercaya (credible signal) mengenai kualitasnya ke pasar modal (Khairudin \& Wandita, 2017). Pengumuman informasi akuntansi memberikan sinyal bahwa perusahaan mempunyai prospek yang baik atau buruk di masa mendatang. Apabila informasi keuangan memiliki penilaian yang baik maka informasi yang diterima investor merupakan good news sehingga investor tertarik untuk melakukan perdagangan saham dan berujung pada perubahan harga saham. Sebaliknya bila informasi keuangan menunjukkan penilaian buruk maka informasi yang diterima investor adalah bad news dan mempengaruhi perdagangan serta harga saham pula.

Jika pengumuman informasi keuangan tersebut mengandung nilai positif, maka diharapkan pasar akan bereaksi pada waktu pengumuman tersebut diterima oleh pasar (Sudarsono \& Sudiyatno, 2016). Pada waktu informasi diumumkan dan semua pelaku pasar sudah menerima informasi tersebut, pelaku pasar terlebih dahulu menilai dan menganalisis informasi tersebut sebagai sinyal baik (good news) atau sinyal buruk (bad news). Jika pengumuman informasi keuangan tersebut merupakan sinyal baik bagi investor, maka akan ada perubahan dalam volume perdagangan saham. Hal tersebut akan mempengaruhi nilai dan return saham suatu perusahaan. Sinyal tersebut dapat tercermin dalam bentuk rasio-rasio yang dapat diukur untuk mengetahui pengaruhnya terhadap return saham.

\subsection{Return Saham}

Kegiatan investasi merupakan kegiatan menempatkan dana pada satu atau lebih aset selama periode tertentu dengan harapan dapat memperoleh pendapatan/keuntungan atau peningkatan atas nilai investasi awal (modal) yang bertujuan untuk memaksimalkan hasil (return) di masa mendatang (Sudarsono \& Sudiyatno, 2016). Keuntungan investasi di pasar 
modal dicerminkan melalui perolehan dari return atas saham yang dipilih. Return merupakan imbalan atas keberanian investor dalam menanggung risiko atas investasi yang dilakukannya.

Return saham dibedakan menjadi dua yaitu return realisasi yaitu return yang telah terjadi atau dapat juga disebut return sesungguhnya, dan return ekspektasi yaitu return yang diharapkan oleh investor atau belum terjadi di masa mendatang (Mayuni \& Suarjaya, 2018). Pengukuran return realisasi/ historikal adalah hal yang penting bagi investor untuk menentukan seberapa baik kinerja aktiva finansial yang dipilih sekaligus digunakan untuk mengestimasi return di masa yang akan datang (Mayuni \& Suarjaya, 2018). Apabila harga saham pada akhir periode melebihi harga saham ketika awal periode, maka investor dinyatakan memperoleh capital gain dan investor dikatakan memperoleh capital loss jika pada akhir periode, harga saham lebih besar dari awal periode (Mayuni \& Suarjaya, 2018).

Kenaikan dan penurunan saham disebabkan oleh berbagai macam faktor yang mempengaruhinya (Sudarsono \& Sudiyatno, 2016). Faktor-faktor yang mempengaruhi harga saham adalah faktor makro dan faktor fundamental. Faktor ekonomi makro berasal dari permasalahan ekonomi secara luas sebagai contoh kebijakan ekonomi, inflasi, tingkat suku bunga, nilai tukar mata uang, pendapatan masyarakat dan lain-lain. Faktor fundamental adalah faktor-faktor yang berasal dari dalam perusahaan yang mengeluarkan saham itu sendiri (emiten). Faktor fundamental ini bisa dilihat dari laporan keuangan, dan dari laporan keuangan emiten bisa dilihat tingkat kinerja keuangan nya baik dari segi kemampuan menghasilkan keuntungan (profitabilitas), kemampuan membayar hutang (solvabilitas), maupun tingkat efisiensi dan efektivitasnya dalam mengelola kekayaannya (aktivitas).

\subsection{Likuiditas}

Setiap perusahaan memerlukan kas untuk menjalankan kegiatan operasional perusahaan seperti membeli bahan baku, membayar upah dan gaji pekerja, melunasi kewajiban jangka pendek, dan membagikan dividen kepada para pemegang saham. Menurut Likuiditas merupakan kemampuan perusahaan untuk menghasilkan kas dalam jangka pendek untuk memenuhi kewajibannya dan bergantung pada arus kas perusahaan (Anwar, 2020). Likuiditas merupakan kunci utama dalam upaya mempertahankan suatu usaha (Muslih, 2019). Likuiditas juga berarti perusahaan mempunyai cukup dana di tangan untuk membayar tagihan pada saat jatuh tempo dan berjaga-jaga terhadap kebutuhan kas yang tidak terduga. Masalah likuiditas penting dalam menjaga kelancaran operasional perusahaan serta kebutuhan jangka pendek dan darurat serta fungsi pertumbuhan (investasi) untuk mengembangkan aset yang dimiliki sesuai dengan harapan yang diinginkan perusahaan. Rasio likuiditas berfungsi untuk menunjukan atau mengukur kemampuan perusahaan dalam memenuhi kewajiban yang jatuh tempo, baik kewajiban kepada pihak luar perusahaan (likuiditas badan usaha) maupun di dalam perusahaan (Sudarman, 2017).

\subsection{Solvabilitas}

Rasio solvabilitas merupakan rasio yang digunakan untuk mengukur sejauh mana aset perusahaan dibiayai dengan utang (Sudarman, 2017). Dalam arti luas rasio tersebut dipakai untuk mengukur sejauh mana asset perusahaan dibiayai dari kewajiban. Hal tersebut berarti besarnya kewajiban yang ditanggung perusahaan dibandingkan dengan aktivanya. Pada 
umumnya, rasio solvabilitas berguna untuk mengetahui seberapa besar solvable dan insolvable suatu perusahaan. Perusahaan memerlukan utang sebagai tambahan modal ketika perusahaan akan melakukan ekspansi, misalnya seperti menambah cabang atau menambah jumlah produksi. Jika seandainya suatu perusahaan nilai rasio solvabilitasnya adalah nol, maka perusahaan dapat dikatakan beroperasi dengan hanya mengandalkan modal sendiri, tanpa terbebani hutang. Semakin tinggi rasio solvabilitas maka akan semakin tinggi resiko kerugian yang akan terjadi, namun terdapat peluang untuk memperoleh profit yang besar pula. Sebaliknya jika perusahaan mempunyai rasio solvabilitas yang rendah maka perusahaan tersebut memiliki resiko kerugian yang lebih kecil. Hal tersebut juga bisa mengakibatkan rendahnya hasil pengembalian ketika usaha sedang maju.

Solvabilitas adalah rasio dapat digunakan untuk menganalisa risiko keuangan yang muncul akibat struktur modal yang berasal dari kebijakan hutang (Warrad, 2016). Pengertian lainnya, kebijakan hutang merupakan keputusan penggunaan hutang dengan mempertimbangkan biaya tetap yang muncul dari hutang berupa bunga, yang akan menyebabkan semakin meningkatnya risiko keuangan dan semakin tidak pastinya tingkat pengembalian bagi para pemegang saham biasa (Wijoyo, 2018). Solvabilitas memberikan gambaran mengenai struktur modal yang dimiliki oleh perusahaan dan juga menunjukkan tingkat hutang perusahaan. Salah satu rasio yang sering digunakan dalam mengukur solvabilitas suatu perusahaan adalah dengan debt equity ratio (DER).

\subsection{Financial Leverage}

Leverage adalah penggunaan aset dan sumber dana (sources of funds) oleh perusahaan yang memiliki biaya tetap agar meningkatkan keuntungan-keuntungan potensial pemegang saham (Setiawan et al., 2019). Jika biaya bersifat variabel, maka akan menghasilkan laba bagi perusahaan, tapi karena sebagai biaya bersifat biaya tetap maka untuk mendapatkan laba diperlukan tingkat pendapatan minuman tertentu. Menurut Hidayat (2019), financial leverage mengacu pada jumlah utang dalam struktur modal perusahaan bisnis. Jika dikaitkan dengan Laporan Posisi Keuangan, financial leverage mengacu pada sisi kanan dari Laporan Posisi Keuangan (komposisi utang dan ekuitas).

Financial leverage merupakan kemampuan perusahaan dalam menggunakan kewajibankewajiban financial tetap untuk meningkatkan pengaruh perubahan EBIT terhadap pendapatan per lembar saham (Setiawan et al., 2019). Penggunaan modal pinjaman (hutang) dalam struktur modal perusahaan ditinjau dari bidang manajemen keuangan, merupakan penerapan kebijakan financial leverage, dimana perusahaan membiayai kegiatan operasionalnya dengan modal pinjaman serta menanggung beban tetap dengan alasan terbatasnya modal sendiri (Hamid \& Kusrina, 2015). Kebijakan ini berhubungan dengan salah satu tujuan dalam pemilihan berbagai alternatif metode pembelanjaan yaitu untuk memperbesar pendapatan bagi pemilik modal perusahaan.

\subsection{Operating Leverage}

Operating leverage dapat didefinisikan sebagai kemampuan perusahaan memanfaatkan biaya tetap untuk menghasilkan laba yang lebih baik bagi perusahaan (Hidayat, 2019). Operating leverage dapat digunakan untuk meningkatkan arus kas dan pengembalian- 
pengembalian (returns). Dan hal tersebut dapat dicapai melalui peningkatan biaya operasi tetap (fixed cost). Kedua metode tersebut bisa berpotensi memunculkan risiko seperti kebangkrutan. Tetapi, jika digunakan dengan tepat akan sangat bermanfaat bagi bisnis.

Operating leverage merupakan penggunaan aktiva dengan menggunakan beban tetap adalah dengan harapan bahwa pendapatan yang didapat oleh pemakaian aktiva itu akan mencukupi untuk menutup beban tetap dan beban variabel (Setiawan et al., 2019. Selain itu, operating leverage diartikan sebagai seberapa besar perusahaan menggunakan beban tetap operasional (Anggreni et al., 2019). Beban tetap operasional tersebut biasanya berasal dari biaya depresiasi, biaya produksi dan pemasaran yang bersifat tetap (misal gaji karyawan). Operating leverage merupakan penggunaan aktiva dengan biaya tetap yang bertujuan untuk menghasilkan pendapatan (Syaifullah, 2018). Analisis operating leverage digunakan untuk mengukur tingkat kepekaan penjualan terhadap EBIT (Syaifullah, 2018).

\subsection{Firm Size}

Firm size adalah ukuran besar kecilnya suatu perusahaan yang membedakan perusahaan menjadi perusahaan big (besar) dan small (kecil) (Hidayat et al., 2019). Selain itu, ukuran perusahaan dapat diartikan suatu skala dimana dapat diklasifikasikan besar kecilnya perusahaan menurut berbagai cara, antara lain: total aktiva, penjualan, log size, nilai pasar saham, kapitalisasi pasar, dan lain-lain yang semuanya berkorelasi tinggi (Sudarsono \& Sudiyatno, 2019). Ukuran perusahaan merupakan salah satu faktor yang dipertimbangkan dalam menentukan berapa besar kebijakan keputusan pendanaan (struktur modal) dalam memenuhi ukuran atau besarnya aset perusahaan (Hidayat et al., 2019). Menurut Andersson (2016), ukuran perusahaan dapat mempengaruhi kemampuan, manfaat dari diversifikasi, skala ekonomi, dan kredibilitas.

\subsection{Pengembangan Hipotesis}

\section{Pengaruh antara Likuiditas terhadap Return Saham Perusahaan}

Kemampuan likuiditas perusahaan terkait dengan kemampuan suatu perusahaan untuk memenuhi kewajiban finansialnya (Sudarman, 2017). Suatu perusahaan yang mempunyai kemampuan tersebut, sehingga dapat memenuhi segala kewajiban finansialnya sesuai jatuh tempo, dapat dikatakan sebagai perusahaan yang likuid. Sebaliknya, bagi perusahaan yang tidak mempunyai hal tersebut dikatakan perusahaan yang inlikuid. Kemampuan tersebut berasal dari aktiva lancar yaitu uang kas dan aktiva lancar lainnya yang dapat diharapkan untuk dicairkan atau ditukarkan menjadi uang tunai yang digunakan untuk pembiayaan paling lama satu tahun. Kemampuan tersebut dapat tergambar dalam cash ratio. Likuiditas yang tinggi memang menarik dari sudut pandang kreditor, namun dari sudut pandang investor, hal ini kurang menguntungkan karena menunjukan adanya indikasi penggunaan aktiva lancar yang tidak efektif (Sudarman, 2017). Sebaliknya, likuiditas yang rendah, walaupun lebih berisiko, menunjukkan bahwa manajemen telah mengoperasikan aktiva lancar secara efektif. Rasio likuiditas yang semakin tinggi seharusnya akan menurunkan return saham perusahaan. Dengan demikian, hipotesis pertama dalam penelitian ini adalah:

$\mathrm{H}_{1}$ : Rasio likuiditas berpengaruh negatif terhadap return saham perusahaan. 


\section{Pengaruh antara Solvabilitas terhadap Return Saham Perusahaan}

Struktur modal yang optimal merupakan salah satu cara untuk meningkatkan harga pasar saham (Wijaya, 2018). Perusahaan dengan hutang yang sangat besar akan memberikan beban berat sehingga perlu adanya keseimbangan dalam menggunakan sumber dana tersebut untuk memaksimalkan nilai perusahaan. Debt to equity ratio (DER) akan menunjukkan bagaimana tingkat hutang perusahaan. perusahaan pasti membutuhkan tambahan dana untuk memperkuat usahanya, sehingga tambahan dana tersebut dipenuhi dari pihak lain karena dana yang dimiliki tidak mencukupi. Sebagai bentuk tanggung jawab atas besarnya hutang tersebut akan menjadikan perusahaan memasang target untuk mempunyai kinerja yang lebih baik, Hal tersebut dapat meningkatkan nilai perusahaan di mata kreditur maupun pada calon investor, sehingga akan meningkatkan return saham dari perusahaan. Solvabilitas perusahaan yang tinggi akan meningkatkan return saham perusahaan. Dengan demikian, hipotesis kedua dalam penelitian ini adalah:

$\mathrm{H}_{2}$ : Solvabilitas berpengaruh positif terhadap return saham perusahaan.

\section{Pengaruh Operating Leverage terhadap Return Saham Perusahaan}

Operating leverage merupakan penggunaan aktiva dengan biaya tetap yang bertujuan untuk menghasilkan pendapatan yang cukup untuk menutup biaya tetap dan biaya variabel serta dapat meningkatkan profitabilitas (Syaifullah, 2018). Analisis operating leverage digunakan untuk mengukur tingkat kepekaan penjualan terhadap EBIT. Operating leverage ini bisa terjadi karena ada biaya tetap dalam struktur biaya perusahaan. Menurut Syaifullah (2018), operating leverage perusahaan mendorong peningkatan pertumbuhan penjualan. Pertumbuhan penjualan mengindikasikan kemampuan perusahan dalam menghasilkan laba, hal ini akan meningkatkan kepercayaan investor untuk menanamkan modal karena tingkat pertumbuhan penjualan diperkirakan akan tinggi. Selain itu dengan adanya peningkatan EBIT ada harapan dari investor untuk mendapatkan dividen dari perusahaan. Adanya kenaikan nilai saham dan pendapatan dividen tersebut akan meningkatkan return saham perusahaan tersebut. Dengan demikian, hipotesis ketiga dalam penelitian ini adalah:

$\mathrm{H}_{3}$ : Operating leverage berpengaruh positif terhadap return saham perusahaan.

\section{Pengaruh Financial Leverage terhadap Return Saham Perusahaan}

Financial leverage merupakan penggunaan dana dengan beban tetap dengan harapan atas penggunaan dana tersebut akan memperbesar EPS (Syaifullah, 2018). Financial leverage dapat didefinisikan sebagai penggunaan potensial biaya-biaya keuangan tetap untuk meningkatkan pengaruh perubahan dalam laba sebelum bunga dan pajak EBIT terhadap EPS (Syaifullah, 2018). Peningkatan EPS ini akan mempengaruhi permintaan terhadap saham perusahaan oleh investor sehingga harga saham perusahaan akan meningkat. Hal ini tentu saja akan menguntungkan bagi para pemegang saham perusahaan. Dengan tingginya tingkat permintaan saham perusahaan, akan meningkatkan harga saham, sehingga hal tersebut akan meningkatkan juga return saham perusahaan tersebut. Financial leverage perusahaan tinggi mendorong peningkatan return saham. Oleh karena itu, hipotesis keempat dalam penelitian ini adalah:

$\mathrm{H}_{4}$ : Financial leverage berpengaruh positif terhadap return saham perusahaan 


\section{Metode Penelitian}

Penelitian ini menggunakan metode kuantitatif. Data yang digunakan dalam penelitian ini adalah data perusahaan di subsektor properti dan real estate yang listed di BEI selama tahun 2012 s.d. tahun 2019. Data penelitian diperoleh dari situs www.idx.co.id, www.idnfinancials.com, dan situs perusahaan. Pemilihan sampel dalam penelitian ini dilakukan secara purposive sampling dengan beberapa kriteria. Pertama, perusahaan properti dan real estate yang go public dan tidak delisting selama periode penelitian di BEI tahun 2012 s.d. tahun 2019. Kedua, Perusahaan properti dan real estate yang mempublikasikan laporan keuangan tahunan yang telah diaudit secara terus menerus selama periode penelitian. Ketiga, Perusahaan properti dan real estate yang memiliki DOL dan DFL dengan nilai kurang dari 20 dan lebih dari -20 berturut-turut selama 2012 s.d. 2019. Berdasarkan kriteria, pengambilan sampel secara purposive sampling penelitian ini dilakukan sebanyak 112 observasi.

Variabel dependen dalam penelitian ini adalah return saham, sedangkan variabel independen terdiri dari likuiditas, solvabilitas, operating leverage, dan financial leverage. Selain itu, penelitian ini juga menggunakan variabel kontrol yaitu ukuran perusahaan. Return saham perusahaan dihitung dengan menggunakan proksi return saham sebagaimana proksi yang digunakan oleh Mende \& Rate (2017) dan Sudarman (2017), yaitu harga saham periode berjalan dikurangi dengan harga saham periode sebelumnya $\left(\mathrm{P}_{\mathrm{t}}-\mathrm{P}_{\mathrm{t}-1}\right)$ kemudian dibagi dengan harga saham periode sebelumnya $\mathrm{P}_{\mathrm{t}-1}$. Penelitian ini menggunakan return saham dengan periode tahunan.

Likuditas dalam penelitian ini menggunakan proksi cash ratio sebagaimana proksi yang digunakan oleh Mende \& Rate (2017) dan Sudarman (2017), yaitu cash dan cash equivalent dibagi dengan current liabilities. Solvabilitas dalam penelitian ini menggunakan proksi Debt to Equity Ratio (DER) sebagaimana proksi yang digunakan oleh Sudarsono \& Sudiyatno (2016), Mende \& Rate (2017) dan Sudarman (2017) yaitu total liabilities dibagi dengan total equities. Financial leverage diukur dengan menggunakan degree of financial leverage (DFL) sebagaimana proksi yang digunakan oleh Syaifullah (2018) yaitu percentage change in EPS dibagi dengan percentage change in EBIT. Operating leverage diukur dengan menggunakan degree of operating leverage (DOL) sebagaimana proksi yang digunakan oleh Syaifullah (2018) yaitu percentage change in EBIT dibagi dengan percentage change in Sales. Ukuran perusahaan dalam penelitian ini mengikuti proksi yang digunakan oleh Sudarsono \& Sudiyatno (2016) yang dihitung dengan logaritma total assets.

Adapun model peneltian ini adalah sebagai berikut.

$$
\operatorname{RETURN}_{i t}=\alpha_{0}+\beta_{1} C R_{i t}+\beta_{2} D E R_{i t}+\beta_{3} D F L_{i t}+\beta_{4} D O L_{i t}+\beta_{5} S I Z E_{i t}+\varepsilon_{i t}
$$

\section{Keterangan:}

RETURN = Return saham $; I=$ Perusahaan Subsektor Properti dan Real Estate $; t=$ Tahun 2012 s.d. tahun 2019; $C R=$ Likuiditas; DER = Solvabilitas; DFL = Financial leverage; DOL = Operating leverage; SIZE = Ukuran Perusahaan; dan $\varepsilon_{i t}=$ Residu . 


\section{Hasil dan Pembahasan}

Statistik deskriptif dari variabel penelitian dalam penelitian ini ditunjukkan dalam Tabel 1 sebagai berikut:

Tabel 1. Statistik Deskriptif

\begin{tabular}{lcccccc}
\hline & Rt & CR & DER & DFL & DOL & SIZE \\
\hline Mean & 0.104 & 0.702 & 1.049 & 1.404 & 1.804 & 29.525 \\
Med. & -0.035 & 0.362 & 0.692 & 0.993 & 1.339 & 29.773 \\
Max. & 2.158 & 6.033 & 5.255 & 18.440 & 16.525 & 31.759 \\
Min. & -0.742 & 0.054 & 0.035 & -6.144 & -17.901 & 25.752 \\
Std. Dev. & 0.557 & 1.041 & 0.946 & 2.939 & 4.640 & 1.326 \\
Obs. & 112 & 112 & 112 & 112 & 112 & 112 \\
\hline \multicolumn{7}{c}{ Sumber: data diolah } \\
\end{tabular}

Selanjutnya, hasil pengujian hipotesis penelitian dengan mengunakan fixed effect method ditunjukkan dalam Tabel 2.

Tabel 2. Hasil Uji Hipotesis

\begin{tabular}{crrrr}
\hline Var. & \multicolumn{1}{c}{ Coef } & \multicolumn{1}{c}{ t-Stat. } & \multicolumn{1}{l}{ Prob. } & \\
\hline C & 2.614 & 2.066 & 0.041 & $* *$ \\
CR & -0.0004 & -0.008 & 0.496 & \\
DER & 0.206 & 3.486 & 0.000 & $* * *$ \\
DFL & -0.003 & -0.188 & 0.427 & \\
DOL & -0.004 & -0.415 & 0.342 & \\
SIZE & -0.092 & -2.148 & 0.019 & $* *$ \\
R $^{2}$ & & 0.121 & & \\
Adj. R & & 0.080 & & \\
F-Stat & & 2.938 & & \\
Prob(F-Stat) & & 0.015 & & \\
\hline
\end{tabular}

Sumber: data diolah

\section{Pengaruh Likuiditas Terhadap Return Saham}

Hasil penelitian ini menunjukkan bahwa likuiditas tidak berpengaruh signifikan terhadap return saham. Hasil penelitian ini sejalan dengan hasil penelitian yang telah dilakukan oleh Mende \& Rate (2017) dan Sudarman (2017). Hasil penelitian ini menunjukkan bahwa pada perusahaan properti dan real estate, tingkat cash ratio tidak menunjukkan informasi yang berguna bagi investor dalam pengambilan keputusan investasi. Walaupun perusahaan dapat memperoleh jumlah kas tertentu dalam satu periode bukan merupakan ukuran bahwa perusahaan memiliki kinerja yang baik di mata investor. Pengelolaan kas dalam memenuhi kewajiban lancarnya merupakan standar yang perlu dilakukan oleh perusahaan sehingga informasi tersebut bukan merupakan yang dapat dijadikan sebagai ukuran bagi investor dalam menilai kinerja pasar perusahaan.

\section{Pengaruh Solvabilitas Terhadap Return Saham}

Hasil pengujian dalam penelitian ini menunjukkan bahwa solvabilitas berpengaruh positif terhadap return saham. Penelitian ini tidak sejalan dengan hasil penelitian yang telah dilakukan oleh Sudarsono \& Sudiyatno (2016), Mende \& Rate (2017), dan Sudarman (2017). Peningkatan beban terhadap kreditur akan menunjukkan sumber pendanaan perusahaan yang tergantung dari pihak eksternal, serta semakin tingginya tingkat risiko suatu perusahaan. Namun, 
berdasarkan hasil pengujian dalam penelitian ini menunjukkan jika investor memandang bahwa perusahaan yang tumbuh pasti akan memerlukan utang sebagai dana tambahan untuk memenuhi pendanaan perusahaan. Perusahaan pasti membutuhkan tambahan dana untuk memperkuat usahanya, sehingga tambahan dana tersebut dipenuhi dari pihak lain karena dana yang dimiliki tidak mencukupi. Sebagai bentuk tanggung jawab atas besarnya hutang tersebut, maka perusahaan akan akan memasang target kinerja yang tinggi sehingga penerimaan laba dapat mencukupi untuk kewajiban pelunasan hutang

Semakin tingginya beban kewajiban berupa hutang dan bunga yang harus dipenuhi oleh perusahaan ini akan dapat meningkatkan kinerja manajemen dalam menjalankan operasinya. Hal ini akan menjadi sinyal yang baik bagi investor. Investor akan menaruh ekspektasi yang tinggi terhadap kinerja perusahaan tersebut untuk menjalankan operasionalnya dengan lebih baik yang akan tercermin dari tingginya target seperti target penjualan atau target laba perusahaan serta akan diwujudkan dalam bentuk realisasi kinerja perusahaan yang diharapkan akan mencatatkan laba atau return saham yang lebih baik. Hal tersebut dapat meningkatkan nilai perusahaan di mata kreditur maupun pada calon investor, sehingga akan meningkatkan return saham dari perusahaan.

\section{Pengaruh Operating Leverage Terhadap Return Saham}

Hasil penelitian ini menunjukkan bahwa operating leverage tidak berpengaruh terhadap return saham. Hasil Penelitian ini tidak sejalan dengan hasil penelitian yang telah dilakukan oleh Syaifullah (2018). Pada hakekatnya operating leverage perusahaan menunjukkan tingkat pertumbuhan laba yang dicapai oleh perusahaan. Pertumbuhan laba seharusnya mengindikasikan kemampuan perusahan dalam menghasilkan laba. Seyogyanya, kondisi tersebut dapat meningkatkan kepercayaan investor untuk berinvestasi dalam perusahaan tersebut. Adanya peningkatan laba operasi perusahaan mengakibatkan harapan dari investor untuk mendapatkan dividen dari perusahaan.

Namun kenyataannya, informasi ini tidak direspon oleh investor karena kemungkinan investor lebih memperhatikan tingkat pengembalian investasi dari kenaikan harga saham perusahaan dibandingkan dividen yang diberikan oleh perusahaan. Selain itu, investor menganggap bahwa pemberian dividen yang diberikan oleh perusahaan tidak selalu diberikan setiap periode ataupun perusahaan di Indonesia belum tentu memberikan dividen dalam kondisi memperoleh keuntungan di periode berjalan.

\section{Pengaruh Financial Leverage Terhadap Return Saham}

Hasil penelitian ini menunjukkan bahwa financial leverage tidak berpengaruh terhadap return saham. Hasil pengujian dalam penelitian ini sejalan dengan hasil penelitian yang telah dilakukan oleh Syaifullah (2018). Informasi financial leverage seyogyanya dapat digunakan oleh investor dalam pengambilan keputusan investasinya. Financial leverage merupakan penggunaan potensial biaya-biaya keuangan tetap untuk meningkatkan pengaruh perubahan dalam laba sebelum bunga dan pajak EBIT terhadap EPS. Peningkatan EPS ini akan mempengaruhi permintaan terhadap saham perusahaan oleh investor sehingga harga saham perusahaan akan meningkat. Hal ini tentu saja akan menguntungkan bagi para pemegang saham 
perusahaan. Dengan tingginya tingkat permintaan saham perusahaan, akan meningkatkan harga saham, sehingga hal tersebut akan meningkatkan juga return saham perusahaan tersebut.

Namun, hasil pengujian ini menunjukkan bahwa investor tidak merespon informasi tersebut. DFL yang terlalu tinggi atau rendah menunjukan bahwa penggunaan hutang dalam modal perusahaan sangat fluktuatif, financial leverage yang terlalu tinggi juga tidak memberikan dampak yang cukup baik bagi tingkat keuntungan yang diperoleh investor dikarenakan adanya kemungkinan perusahaan mengalami gagal bayar atas utang-utangnya. Sehingga hal tersebut cenderung dipandang oleh investor sebagai suatu risiko yang dapat mengancam investasinya. Perubahan EPS juga tidak sepenuhnya sejalan dengan perubahan EBIT yang ada. Hal tersebut disebabkan dalam EBIT terdapat komponen-komponen pendapatan lain-lain yang diperoleh dari selain kegiatan operasional perusahaan, komponen beban bunga yang dibayarkan kepada kreditur, dan beban pajak yang dibayarkan kepada Pemerintah.

\section{Simpulan, Keterbatasan, dan Implikasi}

Penelitian ini menyimpulkan bahwa likuiditas tidak berpengaruh signifikan terhadap return saham perusahaan. perusahaan yang semakin likuid tidak mempengaruhi investor dalam memilih perusahaan yang akan diinvestasikannya. Solvabilitas berpengaruh positif terhadap return saham perusahaan. Investor menganggap bahwa perusahaan dengan tingkat hutang yang tinggi memiliki kinerja yang lebih optimal. Degree of operating leverage tidak berpengaruh terhadap return saham perusahaan. Kenaikan laba operasi perusahaan dalam satu periode tidak menjadi indikator utama untuk menunjukkan kinerja perusahaan bagi investor dalam memilih perusahaan untuk menanam modalnya. Degree of financial leverage tidak berpengaruh terhadap return saham perusahaan. Kenaikan laba bersih perusahaan tidak menjadi indikator utama untuk menunjukkan kinerja perusahaan bagi investor dalam memilih perusahaan untuk menanam modalnya.

Penelitian ini memiliki beberapa. Pertama, hasil penelitian ini hanya menggunakan sektor tertentu sehingga tidak dapat menggeneralisir untuk seluruh perusahaan yang ada di Indonesia. Kedua, periode yang digunakan dalam penelitian ini meliputi tahun 2012 s.d. tahun 2019. Berdasarkan keterbatasan tersebut, penelitian, penelitian selanjutnya dapat menggunakan periode yang lebih panjang dibandingkan dengan penelitian ini. Selain itu, penelitian selanjutnya dapat menggunakan data perusahaan sektor lainnya untuk dapat membandingkan hasilnya dengan hasil penelitian ini.

Hasil penelitian ini dapat dijadikan rujukan bagi investor dapat melakukan analisis fundamental yang lebih dalam terhadap perusahaan yang akan ditanam modalnya agar terhindar dari perusahaan yang melakukan praktik window dressing laporan keuangan, sehingga keputusan yang diambil tepat dan sesuai dengan tujuan investasi. Selain itu, penelitian ini diharapkan dapat menjadi masukan bagi pengawas pasar modal dalam melindungi kepentingan investor. 


\section{DAFTAR PUSTAKA}

Andersson, Matilda. (2016). The Effects of Leverage on Stock Returns. Bachelor Thesis, Lund University.

Anggreni, P.D. et al. (2017). Pengaruh Operating Leverage, Economic Value Added, dan Market Value Added terhadap Return Saham. e-Journal Univ. Pendidikan Ganesha Jurusan Akuntansi Program S1, 8(2), 1-11

Anwar, Yuniarti et al. (2020). Analisis Rasio Likuiditas dan Rasio Profitabilitas pada Perusahaan Daerah Air Minum Kabupaten Ogan Komering Ulu. Jurnal Ecoment Global: Kajian Bisnis dan Manajemen, 5(1), 56-69.

Astikawati, Y. \& Relita, D.T. (2017). Pengaruh Harga Saham Perusahaan terhadap Transaksi Jual Beli Saham di Pasar Modal Indonesia. Jurnal Profit, 4(2),134-144.

Hamid, A. et al. (2015). Pengaruh Financial Leverage terhadap ROE dan EPS pada Sektor Industri Dasar dan Kimia yang Terdaftar di BEI. Benefit: Jurnal Manajemen dan Bisnis, 19(1), 53-63.

Hidayat Y.S.S.N. et al. (2019). Pengaruh size dan beta terhadap return pada perusahaan kecil dan besar yang terdaftar di BEI periode 2010-2014. Journal of Business and Banking, 9(1), 93-108.

Hidayat, K.S. (2019). Rasio Leverage: Operating Leverage Vs Financial Leverage. Jurnal.id. https://www.jurnal. id/id/blog/leverage-sebagai-rasio-keua ngan/ diakses pada 27 Agustus 2020.

Jamil, Hanif H. \& Utami, Efri D. (2016). Analisis Investasi Saham Subsektor Properti dan Real Estate Di Indonesia. Jurnal CICES, 2(1), 32-41.

Kayo, E.S. (2020). Beda Real Estate dengan Property (Fisik dan Kepemilikan). Saham OK. https://www.sahamok. com/beda-real-estate-dengan-property/ diakses pada 27 Agustus 2020.

Khairudin \& Wandita. (2017). Analisis Pengaruh Rasio Profitabilitas, DER, dan PBV terhadap Harga Saham Perusahaan Pertambangan di Indonesia. Jurnal Akuntansi \& Keuangan, $8(1), 68-84$.

Mayuni, I.A.I \& Suarjaya, G. (2018). Pengaruh ROA, Firm Size, EPS, dan PER terhadap Return Saham pada Sektor Manufaktur di BEI. E-Jurnal Manajemen Unud, 7(8), 40634093.

Mende, Stacy \& Rate P.V. (2017). Pengaruh Likuiditas, Solvabilitas dan Rentabilitas terhadap Return Saham Perusahaan Sektor Properti dan Real Estate yang Tercatat di BEI Periode 2012-2015. Jurnal EMBA, 5(2), 2203-2212.

Muslih. (2019). Pengaruh Perputaran Kas dan Likuiditas (Current Ratio) terhadap Profitabilitas (Return on Asset). Jurnal Krisna: Kumpulan Riset Akuntansi, 11(1), 47-59.

Putra et al. (2019). Dampak dan Upaya Penerapan IFRS pada Pelaporan Keuangan Terhadap Perusahaan di Indonesia. Jurnal Ilmiah Akuntansi dan Keuangan Fair Value, 1(2), 235249.

Setiawan, Egi et al. (2019). Pengaruh DOL \& DFL terhadap Profitabilitas. Business Management and Entrepreneurship Journal, 1(2), 149-157.

Sudarman, La. (2017). Peran Rasio Profitabilitas dalam Memediasi Pengaruh Rasio Likuiditas 
dan Solvabilitas terhadap Return Saham. Jurnal Analisa Akuntansi dan Perpajakan, 1(2), 67-82.

Sudarsono, B. \& Sudiyatno, B. (2016). Faktor-Faktor yang Mempengaruhi Return Saham pada Perusahaan Property dan Real Estate yang Terdaftar pada BEI Tahun 2009 s.d. 2014. Jurnal Bisnis dan Ekonomi (JBE), 23(1), 30-51.

Syaifullah, As'ad. (2018). Analisis Pengaruh Financial Leverage dan Operating Leverage terhadap Stock Return. Inovasi, 14(2), 53-62.

Warrad, Lina. (2016). The Analysis of Capital Structure and Performance on the Jordanian Banks' Share Price. European Journal of Business and Management, 8(20), 113-118.

Wijoyo, Amin. (2018). Faktor-faktor yang Mempengaruhi Nilai Perusahaan pada Perusahaan Property dan Real Estate di BEI. Jurnal Ekonomi, 13(1), 48-61.

Yuliaratih, K.A.S \& Artini L. G.S. (2018). Variabel-variabel yang Mempengaruhi Return Saham pada Perusahaan Property dan Real Estate di BEI. E-Jurnal Ekonomi dan Bisnis, 7(5), 1495-1528. 